\title{
Nitrogen budget in integrated aquaculture systems with Nile tilapia and Amazon River prawn
}

\author{
Fernanda S. David ${ }^{1}$ - Danilo C. Proença ${ }^{1}$ • \\ Wagner C. Valenti ${ }^{1,2}$
}

Received: 31 October 2016/Accepted: 28 March 2017 /Published online: 19 April 2017

(C) Springer International Publishing Switzerland 2017

\begin{abstract}
The present work aims to describe the nitrogen $(\mathrm{N})$ budget in integrated aquaculture systems with Nile tilapia (Oreochromis niloticus) and Amazon River prawn (Macrobrachium amazonicum) in earthen ponds, with and without the addition of different substrates. The experimental design was completely randomized, with three treatments (without a substrate, with a geotextile fabric substrate, and with a bamboo substrate) and four replications. Diet was the major input of $\mathrm{N}$ in the systems, ranging from $\sim 65$ to $71 \%$ and followed by inlet water $(\sim 26-31 \%)$. The portion retained in reared animals and periphyton ranged from $\sim 21$ to $25 \%$ (being $\sim 21-24 \%$ in fish and prawns). The outputs that contributed most to the accumulation and release of $\mathrm{N}$ were, respectively, sediment $(\sim 24-38 \%)$ and N2 ( 30-36\%) emitted to the atmosphere. The addition of substrates did not improve the accumulation of nitrogen in the biomass of the target species. This suggests that the periphyton had a minor role on feed availability. In general, the systems were not efficient in using nitrogen since only $\sim 22 \%$ of all available nitrogen was retained into prawn and tilapia biomass. On the other hand, the emission of $\mathrm{N}_{2}$ (an inert gas) to the atmosphere almost compensated the nitrogen supplied in the diet that was not assimilated by the reared animals and periphyton. In addition, data suggest that the integrated aquaculture in stagnant ponds may sequester substantial amounts of nitrogen from nutrient-rich aquatic environments and could be used as a mitigation tool.
\end{abstract}

Keywords Integrated aquaculture systems $\cdot$ Mass balance $\cdot$ Nitrogen budget $\cdot$ Nitrogen sequester - Periphyton $\cdot$ Substrate

Wagner C. Valenti

valenti@clp.unesp.br

1 Aquaculture Center, CAUNESP-São Paulo State University, Jaboticabal, SP Zip code: 14884-900, Brazil

2 Biosciences Institute, UNESP-São Paulo State University, Coastal Campus, São Vicente, SP Zip code: $11330-900$, Brazil 


\section{Introduction}

Aquaculture is still the fastest growing food-producing sector in the world. In 2014, aquaculture accounted for almost half of all fish for human food (FAO 2016). The sector will continue to expand worldwide in the next years to supply the increasing demand for high-quality proteins. Nevertheless, this development should take place in a responsible manner in order to minimize negative environmental impacts (Bayle-Sempere et al. 2013). The culture of different species sharing the same pond may optimize the use of space, water, and other natural resources. The stocking of species with complementary ecosystem functions allows a more efficient exploitation of nutrients and produces less waste (Diana et al. 2013). Thus, integrated aquaculture systems are a strategy to improve environmental sustainability.

The integrated aquaculture may explore the synergistic interactions of the farmed species. The Nile tilapia (Oreochromis niloticus) and the Amazon River prawn (Macrobrachium amazonicum) have characteristics that allow the exploitation of different niches in ponds. Tilapias swim actively in the water column and feed on plankton (Ibrahim et al. 2015), whereas prawns have benthonic habit and feed mainly on detritus and benthic organisms (Maciel and Valenti 2009). In integrated culture, tilapia may be fed with commercial floating diet, whereas prawns eat tilapia feces and leftover diet (Marques et al. 2016; New and Valenti 2017). Such combination represents the farming of a fed species (Nile tilapia) with an extractive species (Amazon River prawn).

The addition of substrates in tilapia-prawn culture ponds may increase the efficiency of the system. Substrates allow prawns to explore vertical dimensions in ponds, increasing the useful area for benthic species, reducing agonistic encounters and social interactions and accelerating the prawn population development (Tidwell et al. 1999; Tidwell et al. 2000; Santos et al. 2016). The substrates also provide space for periphyton settlement, which can assimilate nutrients from the water column, making them available for the reared species. Some studies have documented the advantages of adding artificial substrates to aquaculture systems (Asaduzzaman et al. 2009; Milstein et al. 2008; Uddin et al. 2008). Nonetheless, information on nutrient use and accumulation in each part of the systems has been reported only for phosphorus (David et al. 2017).

The improvement of aquaculture efficiency requires detailed knowledge of nutrient cycling in the systems. It is essential to understand how nutrients are distributed in the several ecological compartments inside the ponds to manage the system and drive its accumulation in the target species. The first step to understand this process is to know the nutrient budgets, which quantifies the fundamental elements in each compartment. This allows identifying the destination of supplied resources and, thus, changes practices to enhance the system efficiency. Nitrogen is a key element because it is essential for animal nutrition and for the control of environment pollution (Jimenez-Montealegre et al. 2002). A quantitative understanding of nitrogen budget is a prerequisite to achieve waste reduction (Mariscal-Lagarda and PaezOsuna 2014) and decrease the chemical fertilizer dependency (Fernando and Halwart 2000). Thus, the objective of this work is to describe the nitrogen budget in integrated aquaculture systems with Nile tilapia and Amazon River prawn in earthen ponds, by quantifying the nitrogen content in all ecological compartments. In addition, we tested the hypothesis that inserting substrates inside the ponds drives more nitrogen to the target species, increasing the retention in the prawns and tilapia biomass and that such effect varies according to the type of substrate. 


\section{Materials and methods}

\section{Experimental design}

The experiment was conducted at the Crustacean Sector of the Aquaculture Center, São Paulo State University, Brazil $\left(21^{\circ} 15^{\prime} 22^{\prime \prime} \mathrm{S}, 48^{\circ} 18^{\prime} 48^{\prime \prime} \mathrm{W}\right)$. Juveniles of M. amazonicum $(0.03 \pm 0.01 \mathrm{~g})$ were stocked in 12 earthen ponds (pond soil termed oxisol, $\sim 0.01$ ha and $1 \mathrm{~m}$ of water depth) at a density of 21.5 individuals per $\mathrm{m}^{2}$. After 5 weeks, juveniles of O. niloticus $(29.0 \pm 1.1 \mathrm{~g})$ were stocked in the same ponds at a density of 1.16 individuals per $\mathrm{m}^{2}$ beginning the integrated culture. Three treatments were tested: (1) without a substrate (WS), (2) with a substrate made of geotextile fabric (GS), and (3) with a substrate made of bamboo (BS). Four replicates of each treatment were assigned randomly to the ponds.

\section{Pond management}

The sediment accumulated on pond bottoms from previous experiments was totally removed. After that, the ponds were filled with nutrient-rich water from a reservoir that receives effluents from fish culture. During the rearing cycle, water was not exchanged and was added only to replace the water lost from evaporation and seepage. Except for the control group, each pond received substrates equivalent to $50 \%$ of its water surface area (Tidwell et al. 2004). The substrates $(\sim 7 \mathrm{~m}$ long $\times \sim 1 \mathrm{~m}$ wide, and $\sim 1.5 \mathrm{~mm}$ thick in the case of the geotextile fabric, and $\sim 4.5 \mathrm{~mm}$ thick in the case of bamboo) were arranged vertically in the ponds and supported with plastic-bottle floats. Additional substrates were installed inside net fences to prevent predation and were used for periphyton analysis. All ponds were fertilized with urea and simple superphosphate at the rate of $2 \mathrm{~kg} \mathrm{~N}$ per ha and $8 \mathrm{~kg} \mathrm{P}_{2} \mathrm{O}_{5}$ per ha, and then were left for 10 days to allow plankton and periphyton growth. After this period, prawns and tilapias were stocked according to the experimental design.

The same feeding regime was used in all ponds. The prawns were fed with pelletized diet (35\% crude protein) at a rate of $10 \%$ of body weight, twice daily until the tilapias were stocked, and then were no longer fed. Tilapias were fed daily with a pelletized diet $(40 \%$ crude protein in the first month and $28 \%$ for the rest of the culture period) at a rate of 4-2\% of tilapia biomass, adjusted monthly. The feed was provided in two equal portions, at 12:00 and 16:00 $\mathrm{h}$ daily. The leftover feed not consumed by tilapias after $15 \mathrm{~min}$ of each feeding time was removed from the ponds and discounted from the values of diet supplied. Each month, 30 tilapias were randomly sampled and weighed to recalculate the daily feed and were then returned to the ponds.

\section{Pond water quality}

Temperature and dissolved oxygen (DO) were monitored daily and $\mathrm{pH}$ was measured weekly (Table 1). These parameters were determined in situ (at 20-30 cm below the water surface) at 08:00 h, using a YSI Professional Plus digital meter (Yellow Springs Instruments, Yellow Springs, OH, USA). Emergency aerators were turned on when DO declined below $1.5 \mathrm{mg} \mathrm{L}^{-1}$. Total ammonia nitrogen (APHA 2005; 4500- $\mathrm{NH}_{3} \mathrm{~F}$. Phenate method), nitrite nitrogen (APHA 2005; 4500- $\mathrm{NO}_{2-}$ B. Colorimetric method), nitrate 
Table 1 Means $( \pm \mathrm{SD})$ of water quality parameters obtained from the treatments without substrate (WS), with geotextile substrate (GS), and with bamboo substrate (BS). Minimum and maximum values reached are shown inside parentheses. No significant differences were observed among treatments

\begin{tabular}{|c|c|c|c|}
\hline \multirow[t]{2}{*}{ Water quality parameters } & \multicolumn{3}{|l|}{ Treatments } \\
\hline & WS & GS & BS \\
\hline $\mathrm{T}\left({ }^{\circ} \mathrm{C}\right)$ & $\begin{array}{r}27.1 \pm 0.9 \\
(20.5-29.4)\end{array}$ & $\begin{array}{r}27.1 \pm 0.9 \\
(20.5-29.3)\end{array}$ & $\begin{array}{r}27.1 \pm 0.9 \\
(22.7-29.5)\end{array}$ \\
\hline $\mathrm{DO}(\mathrm{mg} / \mathrm{L})$ & $\begin{array}{l}4.5 \pm 1.3 \\
(0.8-9.4)\end{array}$ & $\begin{array}{l}4.0 \pm 1.5 \\
(0.8-9.2)\end{array}$ & $\begin{array}{l}4.1 \pm 1.2 \\
(0.8-9.0)\end{array}$ \\
\hline $\mathrm{pH}$ & $\begin{array}{l}7.87 \pm 0.45 \\
(7.18-9.13)\end{array}$ & $\begin{array}{l}7.88 \pm 0.15 \\
(7.21-8.79)\end{array}$ & $\begin{array}{l}7.71 \pm 0.20 \\
(7.14-8.25)\end{array}$ \\
\hline $\mathrm{N}-\mathrm{NH}_{3}(\mu \mathrm{g} / \mathrm{L})$ & $\begin{array}{l}138 \pm 35 \\
(17-561)\end{array}$ & $\begin{array}{l}144 \pm 30 \\
(26-465)\end{array}$ & $\begin{array}{l}109 \pm 24 \\
(7-303)\end{array}$ \\
\hline $\mathrm{N}-\mathrm{NO}_{2-}(\mu \mathrm{g} / \mathrm{L})$ & $\begin{array}{l}8.1 \pm 3.6 \\
(0.2-69.4)\end{array}$ & $\begin{array}{l}11.2 \pm 3.2 \\
(0.6-70.7)\end{array}$ & $\begin{array}{c}5.8 \pm 1.6 \\
(0.4-21.1)\end{array}$ \\
\hline $\mathrm{N}-\mathrm{NO}_{3-}(\mu \mathrm{g} / \mathrm{L})$ & $\begin{array}{l}53.0 \pm 27.0 \\
(1.8-241.8)\end{array}$ & $\begin{array}{l}85.6 \pm 25.3 \\
(1.5-270.3)\end{array}$ & $\begin{array}{l}43.2 \pm 24.5 \\
(1.4-168.9)\end{array}$ \\
\hline Transparency $(\mathrm{cm})$ & $\begin{array}{l}34.6 \pm 2.1 \\
(8-74)\end{array}$ & $\begin{array}{l}39.5 \pm 4.7 \\
(13-82)\end{array}$ & $\begin{array}{l}35.0 \pm 4.7 \\
(13-74)\end{array}$ \\
\hline TSS (mg/L) & $\begin{array}{l}32.0 \pm 23.1 \\
(8.1-85.1)\end{array}$ & $\begin{array}{l}32.2 \pm 24.6 \\
(9.3-76.9)\end{array}$ & $\begin{array}{l}29.7 \pm 19.1 \\
(9.7-57.4)\end{array}$ \\
\hline
\end{tabular}

nitrogen (APHA 2005; 4500- $\mathrm{NO}_{3}$ - E. Cadmium reduction method), transparency (Boyd 1979; Secchi disc), and total suspended solids (APHA 2005; TSS dried at $103-105{ }^{\circ} \mathrm{C}$ ) were measured biweekly (Table 1).

\section{Harvest}

The experiment ended on the 140th day just before the cold season (mid-autumn). All ponds were dried and totally harvested, and all animals were counted. All fish and a random sample of $10 \%$ of prawns from each pond were weighed (Precision Balance Marte-AS2000C; 0.1 g precision). Survival, individual mean weight, and productivity were determined (Table 2).

Table 2 Means $( \pm$ SD) of production variables obtained from the treatments without substrate (WS), with geotextile substrate (GS), and with bamboo substrate (BS)

\begin{tabular}{lccc}
\hline Production variables & \multicolumn{2}{l}{ Treatments } & \\
\cline { 2 - 4 } & WS & GS & BS \\
\hline O. niloticus & & & $88.0 \pm 3.2$ \\
Survival (\%) & $79.3 \pm 7.4$ & $86.7 \pm 1.2$ & $474.7 \pm 58.5$ \\
Mean wet weight (g) & $521.7 \pm 42.8$ & $493.2 \pm 37.8$ & $4853 \pm 461$ \\
Productivity (kg/ha) & $4794 \pm 196$ & $4988 \pm 404$ & $74.0 \pm 9.3$ \\
M. amazonicum & & & $3.1 \pm 0.5^{\text {ab }}$ \\
Survival (\%) & $76.4 \pm 4.4$ & $3.5 \pm 0.4^{\mathrm{a}}$ & $481 \pm 29$ \\
Mean wet weight (g) & $2.7 \pm 0.2^{\mathrm{b}}$ & $483 \pm 115$ & 29.15 \\
Productivity (kg/ha) & $436 \pm 15$ & & \\
\hline
\end{tabular}

Different letters in the same line indicate significant differences among treatments $(P<0.05)$ 


\section{Nitrogen budget}

To describe the nitrogen $(\mathrm{N})$ budget, we divided the system in ecological compartments of input and output. Subtracting the total $\mathrm{N}$ input $\left(\mathrm{TN}_{\mathrm{in}}\right)$ from the total $\mathrm{N}$ output $\left(\mathrm{TN}_{\text {out }}\right)$, we determined the unaccounted portion (UN). The equations used were as follows:

$$
\begin{gathered}
\mathrm{TN}_{\text {in }}=\mathrm{IW}+\mathrm{RW}+\mathrm{F}+\mathrm{AG}+\mathrm{SF}+\mathrm{SP}+\mathrm{D} \\
\mathrm{TN}_{\text {out }}=\mathrm{OW}+\mathrm{EG}+\mathrm{HF}+\mathrm{HP}+\mathrm{DF}+\mathrm{P}+\mathrm{S} \\
\mathrm{TN}_{\text {in }}-\mathrm{TN}_{\text {out }}=\mathrm{UN}
\end{gathered}
$$

In which IW (inlet water), RW (rainwater), F (fertilizer), AG (absorbed gases), SF (stocked fish), SP (stocked prawns), and D (diet) are referred to the content of $\mathrm{N}$ in the input compartments, and OW (outlet water), EG (emitted gases), HF (harvested fish), HP (harvested prawns), DF (dead fish), $\mathrm{P}$ (periphyton), and $\mathrm{S}$ (sediment) are referred to the content of $\mathrm{N}$ in the output compartments. Positive UN values indicate unaccounted nitrogen in the output, whereas negative values indicate unaccounted nitrogen in the input. Phytoplankton was not analyzed as a system compartment, but its contribution was included in the nitrogen budget when we determined the nitrogen content in water (includes live phytoplankton) and sediment (includes dead phytoplankton).

Nitrogen input by inlet water and output by outlet water were calculated by multiplying total $\mathrm{N}$ concentration by the total inlet or outlet water volume. The $\mathrm{N}$ content in water was determined according to the persulfate method (APHA 2005; 4500-N C.). The N concentration in the inlet water started to be measured on the day of fish stocking (beginning of the integrated culture), whereas the $\mathrm{N}$ concentration in the outlet water was measured on the day before harvesting. The inlet water volume is the total volume of water used to fill the ponds plus the volume added to compensate for the loss from evaporation and seepage. Rainwater samples were collected five times during the experiment. We analyzed all samples and used a mean value of their $\mathrm{N}$ concentration. Rainwater volume was calculated using rainfall data from the UNESP Agrometeorological Station, Jaboticabal. Total precipitation volume in the culture period (measured in $\mathrm{L} \mathrm{m}^{-2}$ ) was adjusted for each pond area, and then multiplied by the mean $\mathrm{N}$ concentration in rainwater. For chemical fertilization, we used the $\mathrm{N}$ concentration provided by the manufacturer.

Samples of stocked and harvested animals were analyzed in triplicate (APHA 2005; 4500Norg), and the mean $\mathrm{N}$ concentration was multiplied by the total biomass of animals. All dead fish were removed from the ponds during the course of the experiment and were treated as an outlet variable. The total dead-fish mass in each pond was multiplied by the $\mathrm{N}$ content retained in fish. The input of $\mathrm{N}$ through feed was calculated by multiplying the $\mathrm{N}$ concentration measured in the diet (APHA 2005; 4500- Norg) by the total amount of diet supplied.

Gaseous nitrogen $\left(\mathrm{N}_{2}\right)$ was estimated monthly by two analyses: diffusive and bubbling (Matvienko et al. 2001). For the first, we evaluated the diffusion at the air-water interface by the balance method with the aid of a diffusion chamber, during the day (between 
10:00-12:00 h) and at night (between 22:00-24:00 h). This methodology allows a partial equilibrium between the gas dissolved in the water and the gas inside the chamber through the diffusion of gas to the water (absorption) or from the water (emission). Thus, a diffusion chamber was placed in contact with the surface of the water and $1 \mathrm{~L}$ of air, collected as close as possible to the air-water interface, was placed inside the chamber. Samples of air inside the chamber were collected in periods of $0,1,2$, and 4 min to determine the gas flow. To capture the bubbles (emission), glass fiber funnels suspended by floats were installed on the surface of ponds. We connected a graduated bottle at the extremity of the funnels to trap the bubbles released within $24 \mathrm{~h}$. The air samples obtained from both methods were placed in transfer tubes for analysis by gas chromatography with TCD detector (Thermal Conductivity Detector from Construmaq, São Carlos, Brazil). The final value corresponds to the sum of absorption (input) or emission (output) during daytime and at nighttime throughout the experiment.

Retained $\mathrm{N}$ in periphyton was analyzed with samples $10 \mathrm{~cm}$ wide by $20 \mathrm{~cm}$ long, collected from the added substrates inside the net fences, 20 to $40 \mathrm{~cm}$ below the water surface. We extracted the periphyton from the substrates using an ultrasonic homogenizer (USC-750, Unique Group) according to Thompson et al. (2002) and analyzed the dry mass (AOAC 1995-934.01). The $\mathrm{N}$ content was analyzed by combustion at high temperature and conversion of samples into gases (CHNS Elementar-Vario Macro Cube with Thermal Conductivity Detector sensor). From the dry-mass sample, we estimated the total mass adhered on the entire substrate in each pond. Then, we multiplied the entire periphyton mass by the total $\mathrm{N}$ content to calculate the $\mathrm{N}$ retained in the substrates.

Sediment samples were collected with a tripton sampler placed on the bottom of each pond for $48 \mathrm{~h}$ biweekly. The tripton sampler was comprised of six 1.876-L PVC tubes, $9.7 \mathrm{~cm}$ in diameter and $25.4 \mathrm{~cm}$ in length, with a total area of $0.045 \mathrm{~m}^{2}$. Samples were dried (AOAC 1995-934.01), weighed, and analyzed to determine the total N content (APHA 2005; 4500Norg). The sediment mass and the $\mathrm{N}$ concentration in the samples were used to estimate the total amount of $\mathrm{N}$ accumulated in the pond bottom for 2 weeks. The total $\mathrm{N}$ load in the sediment was determined by the sum of the $\mathrm{N}$ load in each 2 -week period.

\section{Data analyses}

Survival data was square root arcsine transformed prior to analysis. All data were tested for normality (Shapiro-Wilk) and homoscedasticity (Levene). When both conditions were satisfied, data were subjected to one-way ANOVA ( $F$ test) to verify the differences in variables of water quality, production, and compartments of nitrogen budget among the treatments. Productivity data of prawns were not normal and, therefore, data were subjected to the Kruskal-Wallis test. Statistical analyses were carried out in $R$ software (version 0.98.945), and the level of significance considered was $\alpha=0.05$. When significant differences were detected among treatments, means were compared by Tukey's test.

\section{Results}

The unaccounted nitrogen showed large variability among ponds of the same treatment and did not significantly differ among them (Table 3). Diet was the major input of nitrogen in all treatments, ranging from $\sim 65$ to $71 \%$, followed by inlet water, ranging from $\sim 26$ to $31 \%$ 
Table 3 Means ( \pm SD) of nitrogen budget obtained from the treatments without substrate (WS), with geotextile substrate (GS), and with bamboo substrate (BS). The high values of SD in relation to the mean observed in the unaccounted nitrogen are because of the negative and positive budgets observed in ponds of the same treatment

\begin{tabular}{llcc}
\hline Compartments (kg/ha) & Treatments & & \\
\cline { 2 - 3 } & & & \\
& WS & & \\
\hline Input & & & $346 \pm 31$ \\
$\quad$ Diet & $368 \pm 37$ & $356 \pm 21$ & $164 \pm 27$ \\
Inlet water & $135 \pm 20$ & $161 \pm 52$ & $0.3 \pm 0.0$ \\
Rainwater & $0.3 \pm 0.0$ & $0.3 \pm 0.0$ & $2.0 \pm 0.0$ \\
Fertilizer & $2.0 \pm 0.0$ & $2.0 \pm 0.0$ & $12.5 \pm 8.0$ \\
$\mathrm{~N}_{2}$ absorbed & $6.1 \pm 6.9$ & $0.3 \pm 0.6$ & $5.3 \pm 0.3$ \\
Stocked fish & $5.4 \pm 0.4$ & $5.4 \pm 0.9$ & $0.1 \pm 0.01$ \\
Stocked prawns & $0.2 \pm 0.01$ & $0.1 \pm 0.02$ & $26.6 \pm 4.7$ \\
Output & & $30.8 \pm 6.5$ & $160 \pm 83$ \\
Outlet water & $29.1 \pm 7.7$ & $192 \pm 30$ & $3.9 \pm 1.3^{\mathrm{b}}$ \\
$\mathrm{N}_{2}$ emitted & $162 \pm 71$ & $11.4 \pm 2.0^{\mathrm{a}}$ & $112.3 \pm 11.9$ \\
Periphyton & - & $105.8 \pm 16.7$ & $14.5 \pm 0.7$ \\
Harvested fish & $98.4 \pm 11.0$ & $12.2 \pm 4.0$ & $10.1 \pm 2.6$ \\
Harvested prawns & $11.6 \pm 2.7$ & $10.9 \pm 1.4$ & $129 \pm 37$ \\
Dead fish & $16.5 \pm 5.5$ & $176 \pm 71$ & $72.9 \pm 126.9$ \\
Sediment & $197 \pm 63$ & & \\
Unaccounted & & $-14.2 \pm 36.6$ & \\
Input-output & $1.89 \pm 81.8$ & & \\
\hline
\end{tabular}

Different letters in the same line indicate significant differences among treatments $(P<0.05)$

(Figs. 1, 2, and 3). The other input compartments together ranged from 1.5 to $3.8 \%$. No significant differences among treatments were found in the input compartments (Table 3).

The sediment was the compartment that accumulated more nitrogen inside the ponds ( 24 to $38 \%$ ), and the emission of $\mathrm{N}_{2}$ to the atmosphere was the major process to eliminate nitrogen from the ponds in all treatments (30 to 36\%) (Table 3 and Figs. 1, 2, and 3). An average of $97.5 \%$ of gaseous $\mathrm{N}_{2}$ released to the atmosphere were bubbles formed in the sediment at a rate

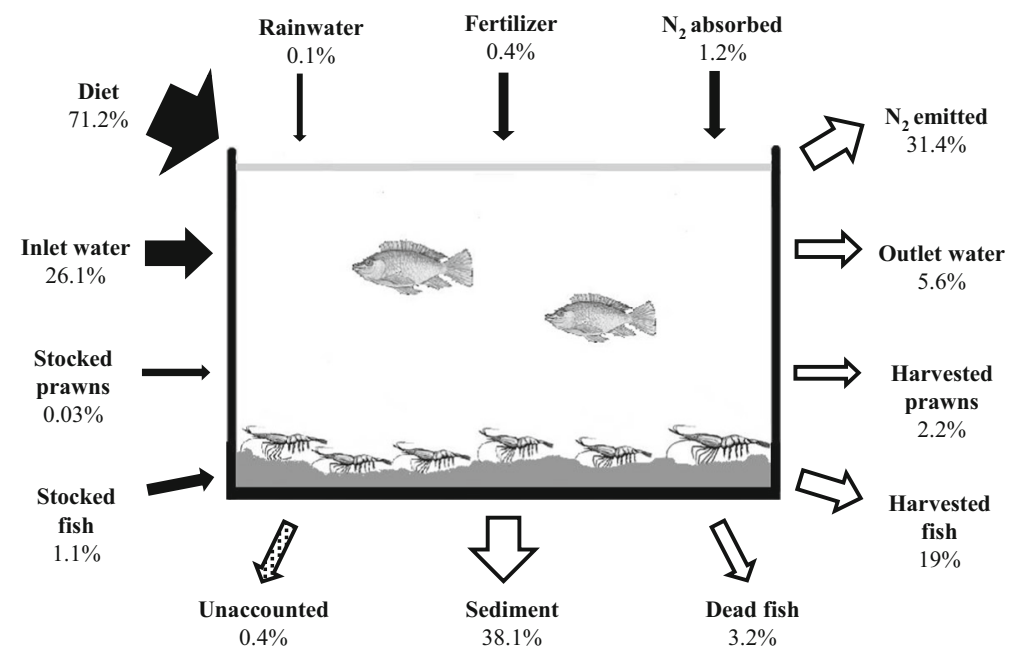

Fig. 1 Nitrogen budget in treatment without substrate (WS). Values are shown in percentages based on the total input to pond 


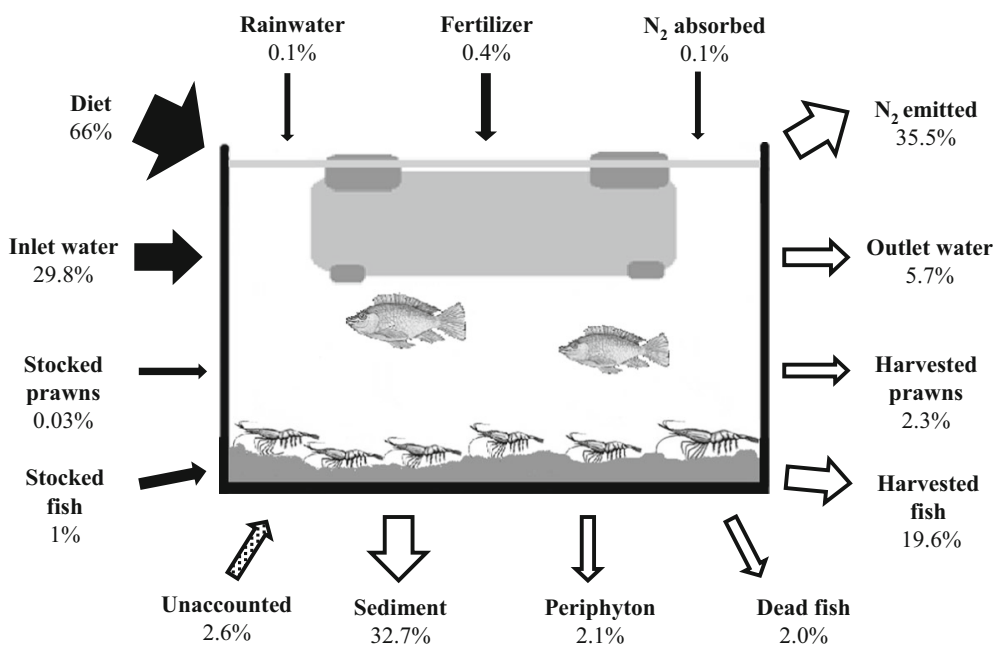

Fig. 2 Nitrogen budget in treatment with substrate made of geotextile fabric (GS). Values are shown in percentages based on the total output from pond

ranging from $\sim 112$ to $123 \mathrm{mg} / \mathrm{m}^{2} / \mathrm{d}$. Nitrogen retained in reared animals and periphyton ranged from $\sim 21$ to $25 \%$, being 19.0 to $21.2 \%$ retained in fish, 2.2 to $2.7 \%$ in prawns, and 0.7 and $2.1 \%$ in periphyton. The nitrogen content in periphyton was significantly higher in GS than in BS treatment $(F=38.75, d f=7, N=12, P=7.94 \mathrm{E}-04$ ) (Table 3 ). The nitrogen input by diet recovered by fish ranged from $\sim 27$ to $33 \%$. Outputs in the outlet water during harvest ranged from $\sim 5$ to $6 \%$. The nitrogen load that entered the system with the inlet water was approximately sixfold the load that returned to the environment with the outlet water. The culture process removed $106 \pm 26,130 \pm 57$, and $137 \pm 24 \mathrm{~kg} \mathrm{~N}$ per ha of ponds in WS, GS, and BS treatments, respectively. Nitrogen in dead fish ranged from $\sim 2$ to $3 \%$.

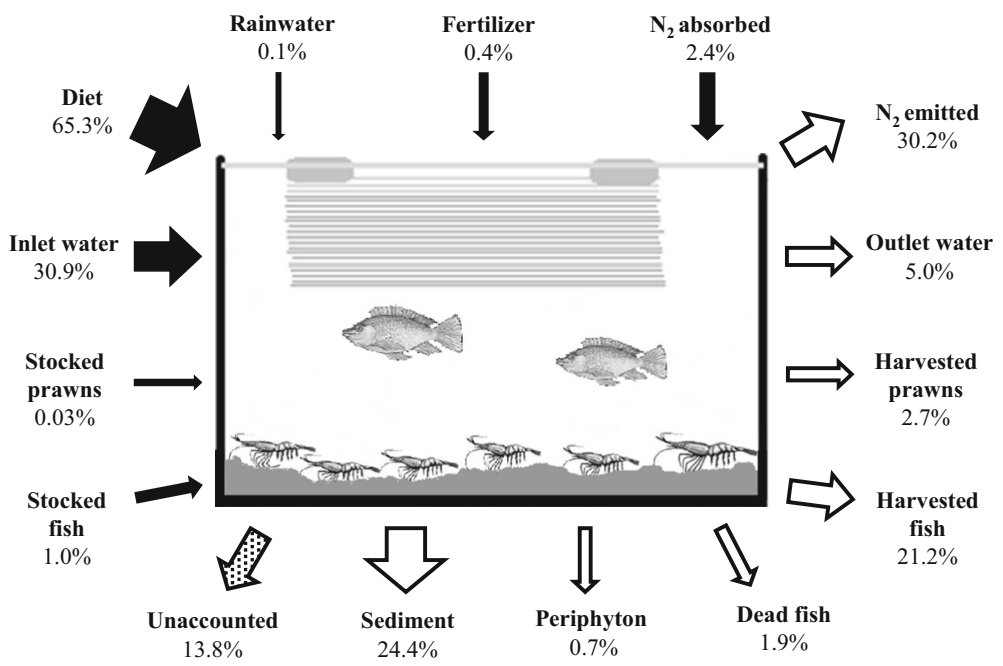

Fig. 3 Nitrogen budget in treatment with substrate made of bamboo (BS). Values are shown in percentages based on the total input to pond 


\section{Discussion}

Contrary to expectations, the addition of substrates had low effect on nitrogen balance of prawn-tilapia integrated culture. In general, no significant differences were observed in the content of nitrogen in each compartment and thus the nitrogen budget was similar in ponds with and without substrates. Furthermore, substrates did not improve the recovery of nitrogen or the accumulation in the biomass of cultured species. Less than $2.5 \%$ of the added nitrogen was retained by periphyton. These unforeseen results indicate low productivity of periphyton or small substrate area available for colonization.

The amount of nitrogen incorporated into fish and prawn biomass was low, but the amount removed from the water was high. Nitrogen entered in the system mainly by the diet supplied to tilapia $(\sim 65-71 \%)$ and by the inlet water $(\sim 26-31 \%)$. The majority of this nitrogen was accumulated in the pond bottom $(\sim 24-38 \%)$ or released to the atmosphere as $\mathrm{N}_{2}(\sim 30-36 \%)$. Therefore, most of the available nitrogen was lost to the compartments other than the farmed animal biomass. Only $\sim 19-21 \%$ of the total nitrogen input was retained in fish and $\sim 2-3 \%$ in prawns. Thus, $\sim 75 \%$ of available nitrogen was lost to the environment, indicating that the systems are inefficient in the use and retention of this key element. Nevertheless, the systems are very efficient in removing nitrogen from water. Approximately 100-140 kg of nitrogen was removed from the inlet water by each hectare of ponds during the 140 days of culture. The long period of water retention into stagnant ponds, as used in this experiment, allows the sedimentation and denitrification processes, which remove organic and inorganic nitrogen from the water column, reducing the load in the effluents. This is a positive externality of aquaculture and shows that some aquaculture systems may be used in mitigation programs for restoration of aquatic environments rich in nutrients. The nitrogen sequester from the aquatic basin surround is an important ecosystem service that may generate credits to farmers.

Feed is the most representative input of nutrients in aquaculture intensively fed systems. For instance, the addition of nitrogen in shrimp monoculture by feed ranged from $\sim 72$ to $99 \%$ in previous studies, whereas inlet water contributed with $\sim 0.5$ to $14 \%$ (Adhikari et al. 2014; Casillas-Hernandez et al. 2006; Sahu et al. 2013a; Saraswathy et al. 2013). The high contribution of inlet water to total nitrogen input observed in the present work is the result of the large volume of nutrient-rich water used throughout the culture to replenish evaporation and seepage ( $10.8 \%$ daily). The nutrient-rich water is a feasible alternative for aquaculture because it has similar characteristics to the water found in aquaculture ponds and may represent a source of unpaid nutrients since it may be incorporated into reared animals (Kimpara et al. 2011).

The addition of substrates presumably improves the nitrogen retention in reared animals. This gain would be via the periphyton food web. Tilapia graze more efficiently on the substrates rather than plankton in the water column (Dempster et al. 1993) and prawns have the periphyton as an additional food source (Santos et al. 2016) besides the wastes of tilapia culture. Nonetheless, the addition of substrates did not significantly affect the performance of fish and prawns to retain nitrogen. This suggests that the periphyton had a minor role on feed availability. Conversely, some studies have demonstrated that the addition of substrates in ponds, with areas ranging from 60 to $131 \%$ of the pond surface, increased yield (Tidwell et al. 1999; Uddin et al. 2009; Haque et al. 2015). The production increase is proportional to the surface area of substrates (Tidwell et al. 2000; Tidwell et al. 2002). Perhaps, in the present study, the substrate area (50\% pond surface area) was not enough to produce the amount of periphyton needed to feed the farmed animals or some environmental factor (e.g., unsuitable ratio $\mathrm{C}: \mathrm{N}: \mathrm{P})$ impaired the total periphyton development. 
Nitrogen retained in periphyton was low and differed between bamboo $(0.7 \%)$ and geotextile fabric $(2.1 \%)$ substrates. This difference, however, is related to periphyton dry mass (DM) adhered on different substrates per surface area $\left(12.7 \pm 5.7 \mathrm{~g} \mathrm{DM} \mathrm{m}^{-2}\right.$ for BS and $40.7 \pm 13.8 \mathrm{~g} \mathrm{DM} \mathrm{m}^{-2}$ for GS). The geotextile fabric substrate has a dark coloration, soft texture, and high porosity, which favor periphyton development (Santos et al. 2016). Nonetheless, retained nitrogen trapped within the pores of the geotextile fabric substrate could not be grazed by the reared animals. In addition, the biomass of periphyton available as food for the animals was low in both treatments. Therefore, the effect of both substrates on the recovery of nitrogen by tilapia and prawns was similar and negligible.

Nitrogen recovery of diet input by target species is generally low in aquaculture. In previous studies, it was observed that freshwater fish assimilated 21 to 27\% (Boyd 1985; Siddiqui and Al-Harbi 1999) of nitrogen from diet supplied and 18 to $21 \%$ from total input (Acosta-Nassar et al. 1994; Green and Boyd 1995) in pond monoculture. In prawn pond monoculture, nitrogen recovery of total input is reported to be $\sim 37 \%$ (Sahu et al. 2013b; Adhikari et al. 2014). In the present work, the percentages of nitrogen recovered by fish were $\sim 27$ to $33 \%$ from diet supplied and $\sim 19$ to $21 \%$ from total input, thus, similar to the values reported in the literature. The recovered portion by prawns was lower; since, as a secondary species, they were stocked at low density and no specific diet was supplied. Thus, the productivity and, consequently, the retained nitrogen in prawn biomass were low. Nevertheless, all incorporated nitrogen by prawns represents a gain to the system, as prawns were not fed. It is known that nitrogen recovery by reared animals increases as the system is intensified (Sahu et al. 2013a) and that M. amazonicum tolerates intensification until $80 \mathrm{PL} \mathrm{m}^{-2}$ in monoculture ponds (MoraesValenti and Valenti 2007). Therefore, higher densities of prawns should be tested in future experiments to optimize the nutrient recovery.

Sediment is the major sink of nitrogen in aquaculture ponds. The main sources are uneaten feed, feces, and dead plankton that sink by gravity action (Jimenez-Montealegre et al. 2005). In addition, sediment has a buffering effect, which removes nutrients from the water and stores them (Chien and Lai 1988). The accumulation of nitrogen in the sediment varied from 24 to $38 \%$ of the total load. These values are consistent with other researches, which found $29-47 \%$ in polycultures (Nhan et al. 2008; Sahu et al. 2015) and 14-53\% in monocultures (Thakur and Lin 2003; Sahu et al. 2013b; Saraswathy et al. 2013). The use of pond sediment to fertilize terrestrial cultures may be a way to recover part of this large amount of nitrogen accumulated in the bottom and a rational way to discard this material.

Generally, in aquaculture ponds, the loss of nitrogen in the form of gas is estimated indirectly by the difference between the nitrogen inputs and outputs. Hu et al. (2012) estimated the loss of nitrogen through gaseous emissions as around $20 \%$ of the nitrogen input and Brown et al. (2012) estimated ammonia volatilization and denitrification as $38.4 \%$ of total nitrogen output. In the present work, the loss of gaseous nitrogen $\left(\mathrm{N}_{2}\right)$ to the atmosphere was really measured (not estimated) and varied from 160 to $192 \mathrm{~kg} \mathrm{ha}^{-1}(\sim 30-36 \%$ of total nitrogen output). Nitrous oxide $\left(\mathrm{N}_{2} \mathrm{O}\right)$ is an important greenhouse gas generated in aquatic environments that was not measured in the present work. Hu et al. (2012) reported an average $\mathrm{N}_{2} \mathrm{O}$ emission of $1.69 \mathrm{gN}_{2} \mathrm{O}-\mathrm{N} / \mathrm{kg}$ fish harvested in aquaculture systems. Thus, in the present work, this emission would be around $9 \mathrm{~kg} \mathrm{~N} \mathrm{~N}_{2} \mathrm{O}$ per ha, which means $\sim 6 \mathrm{~kg} \mathrm{~N}$ per ha and $\sim 1 \%$ of total nitrogen output. This amount is insignificant compared with $\mathrm{N}_{2}$ emission.

Molecular nitrogen is formed by denitrification, generally in anaerobic sites of the soil in the pond bottom. Aquatic sediments consist of a thin oxidized layer overlying a thicker anoxic layer, which allows denitrification (Hargreaves 1998). Oxygen inhibits denitrification; 
however, the process indirectly requires oxygen for the production of nitrate, which is the terminal electron acceptor. The reaction occurs primarily near the sediment surface, possibly in anoxic microzones in the oxidized sediment surface layer. The coexistence of oxic and anoxic processes within an oxic environment was shown by Jørgensen (1977), who found that detrital particles of $100 \mu \mathrm{m}$ to several millimeter may have anoxic centers. The quantity of anoxic microzones depends on oxygen consumption rate, oxygen diffusion rate, and particle geometry (Focht and Verstraete 1977). Therefore, intense denitrification may be common in aquaculture ponds. This process is influenced by many factors, like $\mathrm{pH}$, temperature, the concentration of oxygen, nitrate, organic carbon, and population density of denitrifying bacteria. Thus, the emission products vary according to environmental conditions (Hargreaves 1998; Hu et al. 2012). In the present work, around $80 \%$ of nitrogen artificially added through fertilization and diet was incorporated into the target species biomass or was eliminated to the atmosphere as an inert gas. Thus, the high loads of nitrogen added in ponds by commercial diet may result in low environmental impact in the effluent-receiving water bodies. Therefore, denitrification is an important process to make aquaculture environmentally acceptable.

Nitrogen released in the environment in the outlet water ranged from $\sim 5$ to $6 \%$ of total load and was similar in all ponds. The low periphyton biomass did not entrap nutrients enough to decrease the amount of nitrogen in the outlet water of ponds provided with substrates. Similar percentages were found in other cultures with no water exchange, which varied from $\sim 3$ to $8 \%$ (Adhikari et al. 2014; Sahu et al. 2013a, b). Nonetheless, cultures with water exchange showed higher percentages, ranging about $\sim 16$ to 34\% (Casillas-Hernandez et al. 2006; Saraswathy et al. 2013). This suggests that stagnant pond systems are more environment friendly than continuous water flow systems. The nitrogen in water effluent can be recovered by using the discharge water for irrigating agricultural lands. Phan et al. (2009) suggested the direct discharging into rice fields and gardens.

Unaccounted nitrogen (total input less total output) is quite variable in budget studies. Some reported less than 20\% (Martin et al. 1998; Sahu et al. 2013a; Van Khoi and Fotedar 2010, Sahu et al. 2015), whereas others observed values from 27 to 66\% (Boyd 1985; Paez-Osuna et al. 1999). The unaccounted nitrogen is related to the sum of small methodological errors and/or some overlooked compartments. This includes the loss of nitrogen compounds by seepage (Gross et al. 2000); the volatilization of $\mathrm{NH}_{3}$ (Gross et al. 1999) and $\mathrm{N}_{2} \mathrm{O}$ (Hu et al. 2012) to the atmosphere; the fall of leaves, flowers, and dust within the ponds; the development of some small animals and plants inside the ponds; the migration of animals that can enter the system, deposit or consume nutrients, and leave the system; the predation of fish and prawns by terrestrial animals (mainly birds); and others. In the present study, the unaccounted nitrogen ranged from $\sim 0.4$ to $14 \%$ and had no significant differences among treatments, which indicate that generally all compartments were well assessed. The input/output variations of unaccounted portions may also indicate the difficulties to accurately measure the nitrogen content in various compartments. For instance, the high value of unaccounted nitrogen observed in the output of bamboo treatment might indicate an underestimation of the sediment content in the ponds of this treatment.

This paper showed a clear overview of the distribution of nitrogen in each compartment in semi-intensive integrated aquaculture systems. Additional analyses like measuring animal grazing, productivity, and turnover rates of plankton, benthos, and periphyton could help in understanding the system operation. Some alternatives could be tested to investigate the improvement of nitrogen recovery, as the increase in prawn stocking density, the addition of other detritivores-iliophagus (mud-eating) species, the increase of substrate surface area, the reduction of the feed rate in order to force the animals to eat periphyton and wastes, and the use of effluents and sediments to fertilize agricultural sites. 


\section{Conclusions}

The mapping of nitrogen in each compartment of the system allowed understanding of the destination of this nutrient in fish/prawn integrated systems. Data showed that the addition of different types of substrates may not improve the recovery of nitrogen in aquaculture systems, as supposed. This depends on the development of the periphyton on them and the total area of substrates. The systems studied were not efficient in using nitrogen since only $\sim 22 \%$ of all available nitrogen was retained into prawn and tilapia biomass; additional research aiming to improve nitrogen retention should be performed. On the other hand, the emission of $\mathrm{N}_{2}$ (an inert gas) to the atmosphere almost compensated the nitrogen supplied in the diet that was not assimilated by the reared animals and periphyton. In addition, the data suggest that the integrated aquaculture in stagnant ponds may sequester substantial amounts of nitrogen from nutrient-rich aquatic environments and could be used as a mitigation tool.

Acknowledgements We thank the São Paulo Research Foundation-FAPESP (grant no. 2012/18593-5) and the National Council for Scientific and Technological Development-CNPq (grants no. 473199/2011-4 and 306361/ 2014-0) for the financial support provided.

\section{References}

Acosta-Nassar MV, Morell JM, Corredor JE (1994) The nitrogen budget of a tropical semi-intensive freshwater fish culture pond. J World Aquacult Soc 25:261-270

Adhikari S, Sahu BC, Mahapatra AS, Dey L (2014) Nutrient budgets and effluent characteristics in giant freshwater prawn (Macrobrachium rosenbergii) culture ponds. Bull Environ Contam Toxicol 92:509-513

AOAC $\left(16^{\text {th }}\right.$ ed) (1995) Official methods of analysis. International, Washington, DC

APHA (2005) Standard methods for the examination of water and waste water. Washington DC

Asaduzzaman M, Wahab MA, Verdegem MCJ, Mondal MN, Azim ME (2009) Effects of stocking density of freshwater prawn Macrobrachium rosenbergii and addition of different levels of tilapia Oreochromis niloticus on production in $\mathrm{C} / \mathrm{N}$ controlled periphyton based system. Aquaculture 286:72-79

Bayle-Sempere JT, Arreguin-Sanchez F, Sanchez-Jerez P, Salcido-Guevara LA, Fernandez-Jover D, ZetinaRejon MJ (2013) Trophic structure and energy fluxes around a Mediterranean fish farm. Ecol Model 248: 135-147

Boyd CE (1979) Water quality in warm water fish ponds. Auburn University, Alabama

Boyd CE (1985) Chemical budgets for channel catfish ponds. Trans Am Fish Soc 114:291-298

Brown TW, Boyd CE, Chappell JA (2012) Approximate water and chemical budgets for an experimental, inpond raceway system. J World Aquacult Soc 43:526-537

Casillas-Hernandez R, Magallon-Barajas F, Portillo-Clarck G, Paez-Osuna F (2006) Nutrient mass balances in semi-intensive shrimp ponds from Sonora, Mexico using two feeding strategies: trays and mechanical dispersal. Aquaculture 258:289-298

Chien YH, Lai HT (1988) The effect of aged sediments and stocking density on freshwater prawn Macrobrachium rosenbergii culture. Journal of World Aquaculture Society 19:22A-23A

David FS, Proença DC, Valenti WC (2017) Phosphorus budget in integrated multitrophic aquaculture systems with Nile Tilapia, Oreochromis niloticus, and Amazon River prawn, Macrobrachium amazonicum. J World Aquacult Soc (in press)

Dempster PW, Beveridge MCM, Baird DJ (1993) Herbivory in tilapia Oreochromis niloticus: a comparison on phytoplankton and periphyton. J Fish Biol 43:385-392

Diana JS, Egna HS, Chopin T, Peterson MS, Cao L, Pomeroy R, Verdegem M, Slack WT, Bondad-Reantaso MG, Cabello F (2013) Responsible aquaculture in 2050: valuing local conditions and human innovations will be key to success. Bioscience 63:255-262

FAO (2016) The state of world fisheries and aquaculture 2016. Contributing to food security and nutrition for all, Rome 
Fernando CH, Halwart M (2000) Possibilities for the integration of fish farming into irrigation systems. Fish Manag Ecol 7:45-54

Focht DD, Verstraete W (1977) Biochemical ecology of nitrification and denitrification. Adv Microb Ecol 1:135-211

Green BW, Boyd CE (1995) Chemical budgets for organically fertilized fish ponds in the dry tropics. J World Aquacult Soc 26:284-296

Gross A, Boyd CE, Wood CW (1999) Ammonia volatilization from freshwater fish ponds. J Environ Qual 28: 793-797

Gross A, Boyd CE, Wood CW (2000) Nitrogen transformations and balance in channel catfish ponds. Aquac Eng 24:1-14

Haque MR, Islam MA, Rahman MM, Shirin MF, Wahab MA, Azim ME (2015) Effects of C/N ratio and periphyton substrates on pond ecology and production performance in giant freshwater prawn Macrobrachium rosenbergii (De Man, 1879) and tilapia Oreochromis niloticus (Linnaeus, 1758) polyculture system. Aquac Res 46:1139-1155

Hargreaves JA (1998) Nitrogen biogeochemistry of aquaculture ponds. Aquaculture 166:181-212

Hu Z, Lee JW, Chandran K, Kim S, Khanal SK (2012) Nitrous oxide (N2O) emission from aquaculture: a review. Environmental Science \& Technology 46:6470-6480

Ibrahim ANF, Noll MSM, Valenti WC (2015) Zooplankton capturing by Nile tilapia, Oreochromis niloticus (Teleostei: Cichlidae) throughout post-larval development. Zoologia 32:469-475

Jimenez-Montealegre R, Verdegem MCJ, van Dam A, Verreth JAJ (2002) Conceptualization and validation of a dynamic model for the simulation of nitrogen transformations and fluxes in fish ponds. Ecol Model 147: $123-152$

Jimenez-Montealegre R, Verdegem MCJ, van Dam AA, Verreth JA (2005) Effect of organic nitrogen and carbon mineralization on sediment organic matter accumulation in fish ponds. Aquac Res 36:983-995

Jørgensen BB (1977) Bacterial sulfate reduction within reduced microniches of oxidized marine sediments. Mar Biol 41:7-17

Kimpara JM, Tito Rosa FR, Preto BL, Valenti WC (2011) Limnology of Macrobrachium amazonicum grow-out ponds subject to high inflow of nutrient-rich water and different stocking and harvest management. Aquac Res 42:1289-1297

Maciel CR, Valenti WC (2009) Biology, fisheries, and aquaculture of the Amazon River prawn Macrobrachium amazonicum: a review. Nauplius 17:61-79

Mariscal-Lagarda MM, Paez-Osuna F (2014) Mass balances of nitrogen and phosphorus in an integrated culture of shrimp (Litopenaeus vannamei) and tomato (Lycopersicon esculentum mill) with low salinity groundwater: a short communication. Aquac Eng 58:107-112

Marques HLA, New MB, Boock MV, Barros HP, Mallasen M, Valenti WC (2016) Integrated freshwater prawn farming: state-of-the-art and future potential. Reviews in Fisheries Science \& Aquaculture 24(3):264-293

Martin JLM, Veran Y, Guelorget O, Pham D (1998) Shrimp rearing: stocking density, growth, impact on sediment, waste output and their relationships studied through the nitrogen budget in rearing ponds. Aquaculture 164:135-149

Matvienko B, Sikar E, Rosa LP, dos Santos MA, De Filippo R, Cimbleris ACP (2001) Gas release from a reservoir in the filling stage. In: Williams WD (Ed) International Association of Theoretical and Applied Limnology. 27:1415-1419

Milstein A, Peretz Y, Harpaz S (2008) Culture of organic tilapia to market size in periphyton-based ponds with reduced feed inputs. Aquac Res 40:55-59

Moraes-Valenti PMC, Valenti WC (2007) Effect of intensification on grow out of the Amazon River prawn, Macrobrachium amazonicum. J World Aquacult Soc 38:516-526

New MB, Valenti WC (2017) Tilapia-Macrobrachium polyculture. In: Perschbacher PW, Stickney RR (eds) Tilapia in intensive co-culture, 1st edn. Wiley-Blackwell, Oxford

Nhan DK, Verdegem MCJ, Milstein A, Verreth JAV (2008) Water and nutrient budgets of ponds in integrated agriculture-aquaculture systems in the Mekong Delta. Vietnam Aquaculture Research 39:1216-1228

Paez-Osuna F, Guerrero-Galvan SR, Ruiz-Fernandez AC (1999) Discharge of nutrients from shrimp farming to coastal waters of the Gulf of California. Mar Pollut Bull 38:585-592

Phan LT, Bui TM, Nguyen TTT, Gooley GJ, Ingram BA, Nguyen HV, Nguyen PT, De Silva SS (2009) Current status of farming practices of striped catfish, Pangasianodon hypophthalmus in the Mekong Delta, Vietnam. Aquaculture 296:227-236

Sahu BC, Adhikari S, Dey L (2013a) Carbon, nitrogen and phosphorus budget in shrimp (Penaeus monodon) culture ponds in Eastern India. Aquac Int 21:453-466

Sahu BC, Adhikari S, Mahapatra AS, Dey L (2013b) Carbon, nitrogen, and phosphorus budget in scampi (Macrobrachium rosenbergii) culture ponds. Environ Monit Assess 185:10157-10166 
Sahu BC, Adhikari S, Mahapatra AS, Dey L (2015) Nitrogen, phosphorus, and carbon budgets in polyculture ponds of Indian major carps and giant freshwater prawn in Orissa state, India. J Appl Aquac 27:365-376

Santos MR, Rodrigues CG, Valenti WC (2016) Effect of habitat diversity on population development of the Amazon river prawn. J Shellfish Res 35(4):1075-1081

Saraswathy R, Muralidhar M, Kailasam M, Ravichandran P, Gupta BP, Krishnani KK, Ponniah AG, Sundaray JK, Panigrahi A, Nagavel A (2013) Effect of stocking density on soil, water quality and nitrogen budget in Penaeus monodon (Fabricius, 1798) culture under zero water exchange system. Aquac Res 44:1578-1588

Siddiqui AQ, Al-Harbi AH (1999) Nutrient budgets in tanks with different stocking densities of hybrid tilapia. Aquaculture 170:245-252

Thakur DP, Lin CK (2003) Water quality and nutrient budget in closed shrimp (Penaeus monodon) culture systems. Aquac Eng 27:159-176

Thompson FL, Abreu PC, Wasielesky W (2002) Importance of biofilm for water quality and nourishment in intensive shrimp culture. Aquaculture 203:263-278

Tidwell JH, Coyle S, Weibel C, Evans J (1999) Effects and interactions of stocking density and added substrate on production and population structure of freshwater prawns Macrobrachium rosenbergii. J World Aquacult Soc 30:174-179

Tidwell JH, Coyle S, Van Arnum A, Weibel C (2000) Production response of freshwater prawns Macrobrachium rosenbergii to increasing amounts of artificial substrate in ponds. J World Aquacult Soc 31:452-458

Tidwell JH, Coyle S, Van Arnum A, Weibel C (2002) Effects of substrate amount and orientation on production and population structure of freshwater prawns Macrobrachium rosenbergii in ponds. J World Aquacult Soc 33:63-69

Tidwell JH, Coyle SD, Dasgupta S, Bright LA, Yasharian DK (2004) Impact of different management technologies on the production, population structure, and economics of freshwater prawn Macrobrachium rosenbergii culture in temperate climates. J World Aquacult Soc 35:498-505

Uddin MS, Milsten A, Azim ME, Wahab MA, Verdegem M, Verreth J (2008) Effects of stocking density, periphyton substrate and supplemental feed on biological processes affecting water quality in earthen tilapiaprawn polyculture ponds. Aquac Res 39:1243-1257

Uddin MS, Azim ME, Wahab MA, Verdegem MCJ (2009) Effects of substrate addition and supplemental feeding on plankton composition and production in tilapia (Oreochromis niloticus) and freshwater prawn (Macrobrachium rosenbergii) polyculture. 27:99-105

Van Khoi L, Fotedar R (2010) Effects of stocking density on the nutrient budget and growth of the western king prawn (Penaeus latisulcatus Kishinouye) in a recirculating aquaculture system. Aquac Res 41:624-633 